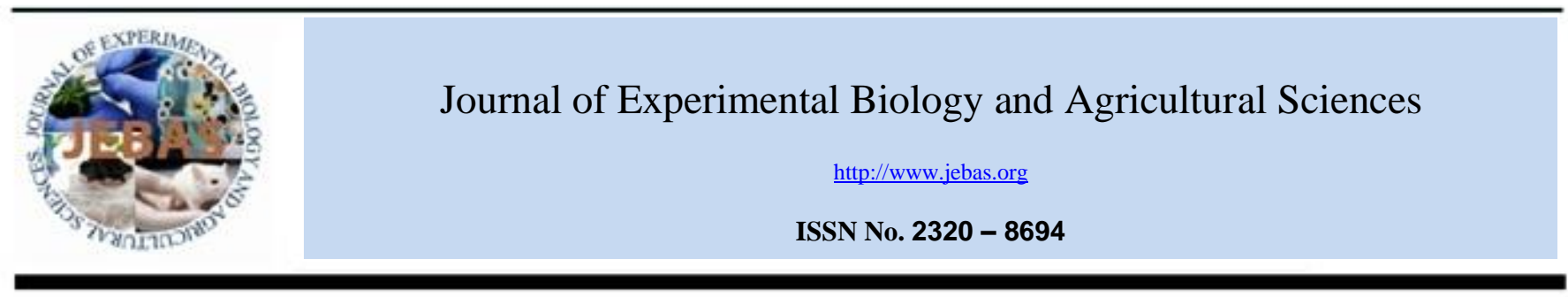

\title{
MOLECULAR CHARACTERIZATIONS OF MICROBIAL ANTAGONISTS AND DEVELOPMENT OF BIOFORMULATIONS FOR MANAGEMENT OF BACTERIAL WILT OF NAGA CHILLI (Capsicum chinens Jacq.) IN ASSAM
}

\author{
Lohit C Bora*, Lohit Kataki, Kuldeep Talukdar, Bharat Ch Nath and Rinku Sarkar
}

Department of Plant Pathology, Assam Agricultural University, Jorhat-785013, Assam, India

Received - September 09, 2014; Revision - October 29, 2014; Accepted - March 02, 2015

Available Online - In Press.

KEYWORDS
Trichoderma parareesei
T. viride
Paecilomyces variotii
Bacillus thuringiensis
Citrobacter farmeri
Consortium bioformulation
Biocontrol
Ralstonia solanacearum

KEYWORDS

Ralstonia solanacearum

\begin{abstract}
Aggressive strains of five different saprophytic antagonists Trichoderma parareesei TPJ-S-1, Trichoderma viride TVJ-S-1, Paecilomyces variotii Isolate-1, Bacillus thuringiensis BTJ-S-1 and Citrobacter farmeri CTJ-S-1 and their consortial formulations were evaluated during 2012-14, for their effectiveness in management of bacterial wilt disease (c. o. Ralstonia solanacearum) of Naga chilli (Capsicum chinens Jacq.). The molecular characterization of selected antagonists was undertaken to determine their distinctiveness from their close relatives through sequencing of the $18 \mathrm{~S} \& 28 \mathrm{~S}$ region of ribosomal DNA in case of fungal antagonists and $16 \mathrm{~S}$ region in case of bacterial antagonists along with its phylogenetic analysis. The antagonistic potential of the five microbes were tested in vitro singly and in consortia against $R$. solanacearum adopting dual culture method. Altogether 31 treatment combinations were compared; the inhibition zones $(\mathrm{mm})$ and percent inhibitions were recorded and analyzed. The highest inhibition (91.47\%) against $R$. solanacearum was recorded in consortia of $T$. parareesei, $T$. viride and $B$. thuringiensis followed by the consortia of $T$. parareesei, $T$. viride, $P$. variotii, B. thuringiensis and C. farmeri $(82.22 \%)$. Quantitative aspect of population dynamics of selected antagonists in three different substrate carrier viz. vermicompost, talcum powder (TP) and mustard oil cake (MOC) were compared to evaluate their shelf-life at different days of storage.
\end{abstract}

\footnotetext{
* Corresponding author

E-mail: boralohitc@gmail.com (Lohit C Bora)

Peer review under responsibility of Journal of Experimental Biology and Agricultural Sciences.
}

Production and Hosting by Horizon Publisher (www.my-vision.webs.com/horizon.html). All rights reserved. 
Naga chilli

Phylogenetic analysis
All substrate based formulations contained carboxy methyl cellulose (CMC), mannitol and chitin as standard additives. A steady population count was recorded in all different substrate based bioformulations up to 270 days of storage at room temperature. However, highest population recovery $\left(112.43 \times 10^{7} \mathrm{cfu} / \mathrm{g}\right)$ was found in vermicompost based formulation $T$. viride followed by vermicompost based T. parareesei $\left(108.83 \times 10^{7} \mathrm{cfu} / \mathrm{g}\right)$ at 270 days of storage. The best three consortial bioformulations having all desired characteristics were selected for field evaluation and applied in plant as combination of seed treatment, soil application and sprays at 30 days after transplanting which showed significant reduction in bacterial wilt incidence and enhanced economic yield of Naga chilli. Maximum disease reduction (83.87\%) was recorded in consortial formulation of $T$. parareesei, $T$. viride, $P$. variotii, B. thuringensis and $C$. farmeri. The treatment also recorded significantly higher yield $(9.68 \mathrm{ton} / \mathrm{ha})$ as compared to other treatment combinations.

\section{Introduction}

India needs about 294 Mt food grains for a projected population of around 1.3 billion by 2020. Furthermore, the projected world population till 2020 will be 7.5 billion. The present chemical intensive high input agriculture is increasingly recognized as environmental degrading and people are now seriously concerned with the protection of the environment and more about safe-guarding their health. Therefore, work on the development of technologies based on natural resources, particularly exploration of the potentials of natural biodiversity has immense scope as alternative for sustainable agriculture.

Plant beneficial microbes (PBM), a component of extensive microbial biodiversity, affect the plant health and development. Some PBM are well known antagonists against soil borne plant pathogens and attempts have been made throughout the world to explore the possibilities of using these saprophytic antagonists for crop disease management (Burr et al., 1978; Papavizas, 1985; Anuratha \& Gnanamanickam, 1990; Bora, 2011). Therefore, to explore the techniques for mass culture and enhance survivability of these antagonists in different organic substrates and develop effective biological formulations are becoming priority research for most of the agricultural scientists associated with biological management of crop diseases.

Vegetables and spices have a vital importance in a balanced diet and are the cheapest source of carbohydrates, vitamins, minerals and proteins. Amongst spices, Naga chilli (bhut jolokia) an interspecies hybrid chilli cultivated in Assam, Nagaland and Manipur region of North East India. Results of molecular characterization study revealed that the chilli is an interspecies hybrid of $C$. chinense ans $C$. frutescens (Bosland \& Baral, 2007). The Guinness Book of World Records certified Naga chilli (bhut jolokia) as the hottest chilli pepper with a heat level of 577,000 SHUs (Bosland \& Baral, 2007). The chemical responsible for such high SHU in Naga chilli is due to presence of high quantity (3-5\%) of powerful alkaloid capsaicin and dihydrocapsaicin. It is the most ideal chilli variety of India for extraction of oleoresin and capsaicin.
Naga chilli crop is highly susceptible for various plant diseases such as bacterial wilt, die-back, anthracnose, leaf curl and leaf necrosis. The intensity of these diseases are higher in Assam as well as other parts of the North-Eastern India. Among these, the bacterial wilt caused by Ralstonia solanacearum (Smith) is one of the most serious diseases of crops in tropics, subtropics and warm temperate regions of the world (James et al., 2003). This disease is endemic to all the agro-climatic zones of the North Eastern states of the India and becomes severe when environmental factor favors disease outbreak. Different management practices such as chemicals, antibiotics, soil amendments, soil solarization etc used for disease management. However, these methods have limitations and do not give results up to the desirable level. Chemicals are costly, besides of posing a risk of environmental hazards. Therefore, there is a growing concern to find out alternative methods by exploiting bioactive antagonists which results in the reduction of the inoculums density or disease producing activities of pathogens in their active or dormant state (Weller \& Cook, 1983). Various biological agents have been employed for management of the plant diseases. Pseudomonas fluoresens recognized as a major bacterial antagonist, which has the ability to suppress various seed, soil and air-borne fungal and bacterial pathogens (Burr et al., 1978; Manoranjitham et al., 2000). Among the antagonistic fungi, Trichoderma sp. have the ability to exert influence on most of the soil borne pathogens through competition, antibiosis, hyper-parasitism, lysis or other forms of antagonism (Chet, 1987). Many entomopathogenic fungi like Verticillium lecani have high potential to inhibit the growth of different plant pathogens besides having lytic properties against insect pests (Askary et al., 1997). Similarly other entomopathogenic fungus Metarhizium anisopliae have ability to produces a family of cyclic peptide toxins, destruxins (DTX). Destruxins are highly effective bioactive compound which worked against a large group of Lepidopteran, Orthopteran and Coleopteran insect pests (Kershaw et al., 1999).

With the above view points, the present study was made to evaluate a management strategy of Naga chilli bacterial wilt by using bioformulations of established and newly isolated microbial bioagents like Trichoderma parareesei, T. viride, 
Paecilomyces variotii, Bacillus thuringiensis and Citrobacter farmeri as well as their consortia formulations.

\section{Materials and Methods}

Various experiments were conducted under laboratory and fields condition at the Department of Plant Pathology, and Assam Agricultural University, Jorhat, during the cropping season of 2012 to 2014.

2.1 Isolation of pathogen and antagonists agent from the experimental site

The bacterial wilt pathogen ( $R$. solanacearum) was isolated from diseased Naga chilli plants showing typical symptoms of wilting by using Triphenyl Tetrazolium Chloride (TTC) medium (Kelman 1954). The antagonists required for the study viz., T. parareesei, T. viride, $P$. variotii, B. thuringiensis and $C$. farmeri were isolated from soils collected from various regions of Assam following the serial dilution plate technique of Waksman (1922). The medium used for isolation of the antagonists are King's B agar medium (King et al., 1954) for $P$. fluorescens, Trichoderma Selective Agar (TSA) medium for Trichoderma sp. (Elad et al., 1981), and for remaining bioagents Potato Dextrose Agar (PDA) and Nutrient agar (NA) media was used for fungal and bacterial antagonists, respectively. The different strains obtained were characterized based on "Bergey's Manual of Determinative Bacteriology". The cultures were routinely maintained on slants at $4^{\circ} \mathrm{C}$ for further studies.

\subsection{Molecular analysis of bio agents}

\subsubsection{Isolation of genomic DNA}

The total genomic DNA was extracted from fungal bioagents following the extraction method as described by Samuels \& Ismaiel (2009) whereas, genomic DNA of bacterial bioagents was extracted and purified according to the method illustrated by Wang et al. (2001). The isolated DNA was quantified and its purity was estimated with the help of Nanodrop 1000 (Thermo Scientific). The absorbance of genomic DNA was measured at $260 \mathrm{~nm}$ to find out the concentration of DNA in solution. The absorbance at $280 \mathrm{~nm}$ was also used to estimate the extent of protein contamination in the extracted DNA.

\subsubsection{Primer sets used for PCR study}

The primer sets used in present investigations were LROR and LR7 (Vilgalys \& Hester, 1990) for amplification of 28S rDNA gene fragment of $T$. parareesei and T. viride; ITS1 and ITS4 for $18 \mathrm{~S}$ rDNA in case of $P$. variotii; $8 \mathrm{~F}$ and $1492 \mathrm{R}$ for $16 \mathrm{~S}$ rDNA gene fragment of bacterial bio agents $B$. thuringiensis and C. farmeri.

\subsubsection{S, $18 \mathrm{~S}$ and $16 \mathrm{~S}$ ribosomal DNA gene sequencing}

Purified fungal and bacterial bio agents were initially identified using rDNA based partial sequencing technique. For direct cycle sequencing, fragments were purified with QI Aquick PCR purification kit (Qiagen) by following manufacturer's instructions. PCR amplification for $28 \mathrm{~S}$ and $18 \mathrm{~S}$ ribosomal DNA fragment was performed in a $50 \mu \mathrm{l}$ reaction volume following the PCR protocol described by Xiaoke et al. (2013) and Hermosa et al.(2000) respectively. For $18 \mathrm{~S}$ rDNA amplification the reaction mixture was $10 \mathrm{ng}$ template DNA, $1 \mu \mathrm{L}$ dNTP mix ( $2.5 \mathrm{mM}$ each), $100 \mathrm{ng} / \mu \mathrm{L}$ each of forward and reverse primer, $1 \mathrm{X}$ Taq DNA polymerase assay buffer (10X), 3U Taq DNA polymerase (Bangalore Genei Ltd., Bangalore, India), and made up $50 \mu \mathrm{L}$ reaction volume. All reactions were done with $5 \mathrm{~min}$ initial denaturation at $94^{\circ} \mathrm{C}$, followed by 35 cycles: $30 \mathrm{~s}$ at $94^{\circ} \mathrm{C}, 30 \mathrm{~s}$ at $54^{\circ} \mathrm{C}, 1 \mathrm{~min}$ at $72^{\circ} \mathrm{C}$ and a final extension of $10 \mathrm{~min}$ at $72^{\circ} \mathrm{C}$. The reactions were carried out in GeneAmp PCR System (Applied Biosystems model 9700). Quality of amplified PCR products were visualized on a 1.0\% agarose gel and purified to remove contaminants using the MinElute PCR purification kit (Qiagen, India), before sequencing. Forward and reverse DNA sequencing was done with respective primer sets used in PCR amplification using BigDye ${ }^{\circledR}$ Terminator v3.1 Cycle Sequencing Kit on ABI 3730xl Genetic Analyzer (Applied Biosystems). The generated gene sequences were used to carry out homology search against previously reported sequences using NCBI BLASTn search engine with default parameters. Based on maximum identity score first ten sequences were selected and the phylogenetic tree was constructed using MEGA 4 software.

\subsubsection{Multiple sequence alignments and phylogenetic analysis}

Phylogenetic analysis of two bioagents viz. T. parareesei TPJ$\mathrm{S}-1$ and B. thuringiensis BTJ-S-1 were done only, as the revolutionary analysis of remaining three bioagents was done earlier by the author. Multiple sequence alignment of the fungal and bacterial bio agents was analyzed using the Molecular Evolutionary Genetics Analysis (MEGA) Software ver. 5.05 (Tamura et al., 2011) using Clustal W function with default parameters. The partial gene sequences of the closest identified relatives (identity $>90 \%)$ of the test bacterial $(B$. thuringiensis BTJ-S-1 $C$ ) and fungal (T. parareesei TPJ-S-1) antagonists were manually imported from NCBI GenBank sequence database and aligned against each $28 \mathrm{~S}, 18 \mathrm{~S}$ and $16 \mathrm{~S}$ rDNA gene sequences separately using this software. From these aligned sequences phylogenetic tree was constructed using the MEGA software through neighbour-joining tree building algorithm (Tajima \& Nei, 1984) the data sets were subjected to 100 bootstraps replicates.

2.4 In vitro evaluation of the efficacy of the isolated antagonists against $R$. solanacearum

The antagonistic potential of the five antagonist's viz., $T$. parareesei, $T$. viride, $P$. variotii, $B$. thuringiensis and $C$. farmeri and their consortia were in vitro tested against $R$. solanacearum by agar plug method in dual culture assays (Aspiras \& Della, 1985). The initial inoculums concentration 
of the pathogen was always adjusted to $1 \times 10^{8}$ colony forming units per milliliter $(\mathrm{cfu} / \mathrm{ml})$ for a bacterial population. Altogether 31 treatment combinations were tested and the antagonistic potential was evaluated on the basis of inhibition zones $(\mathrm{mm})$ and percent inhibitions. A pairs of untreated control plate are also be maintained for comparison. The best four antagonist consortia was selected on the basis of their in vitro antagonistic performance and used for further evaluation of their ability to multiply in different growth substrates so that the bioformulation so obtained could be used to suppress wilt incidence of Naga chilli in vivo.

2.5 Evaluations of growth and multiplication of antagonists in different substrates

Three types of substrates were evaluated with an objective to select the best substrate for mass multiplication of the antagonists. These evaluated substrates were Vermicompost (VC), Talcum powder (TP) and Mustard oil cake (MOC). The substrates were air dried and passed through 350 mesh sieves to obtain fine powders. These were filled into polypropylene bags separately, sealed with non-absorbent cotton plugs and sterilized at $121^{\circ} \mathrm{C}$ for 30 minutes. Mass culture of bacterial antagonists $B$. thuringiensis and $C$. farmeri were prepared by transferring aseptically its $24 \mathrm{~h}$ old growth in NA into $1000 \mathrm{ml}$ nutrient broth and incubated at $28^{\circ} \mathrm{C}$ for $48 \mathrm{~h}$. Similarly, mass cultures of fungal antagonists $T$. parareesei, $T$. viride, $P$. variotii, was prepared by transferring aseptically their $72 \mathrm{~h}$ old growth in PDA to $1000 \mathrm{ml} \mathrm{PD}$ broth and incubated at $28^{\circ} \mathrm{C}$ for $120 \mathrm{~h}$. From these, $10 \mathrm{ml}$ of each bacterial antagonist viz $B$. thuringiensis $\left(10^{7} \mathrm{cfu} / \mathrm{ml}\right), C$. farmeri cells $\left(10^{7} \mathrm{cfu} / \mathrm{ml}\right)$ and fungal antagonist viz $T$. parareesei, $T$. viride and $P$. variotii with $10^{7} \mathrm{cfu} / \mathrm{ml}$ respectively were added to the sterilized substrates contained in the polypropylene bags.

Into all the substrates $10 \mathrm{ml}$ of each 1\% Carboxy-Methyl Cellulose (as standard sticker) and 3\% Mannitol (as standard osmoticant) were added in order to impart greater adherence and higher moisture retaining property respectively to the substrates. The inoculated substrates were then mixed properly and incubated at $28^{\circ} \mathrm{C}$ for $72 \mathrm{~h}$. The bags were stored at room temperature after incubation.

For determination of the population of the antagonists in different substrate formulation after different days of storage as prepared above, shelf life study experiment was designed following CRD with 3 replications. The 16 different treatment combinations were: Vermicompost $+T$. parareesei; Talc powder $+T$. parareese $i$; Mustard oil cake $+T$. parareese $i$; $\mathrm{VC}$ $+T$. viride $; \mathrm{TP}+T$. viride $; \mathrm{MOC}+T$. viride $; \mathrm{VC}+P$. variotii $;$ $\mathrm{TP}+P$. variotii; $\mathrm{MOC}+P$. variotii $; \mathrm{VC}+B$. thuringiensis; $\mathrm{TP}$ + B. thuringiensis; $\mathrm{MOC}+$ B. thuringiensis; $\mathrm{VC}+C$. farmeri; $\mathrm{TP}+C$. farmeri; $\mathrm{MOC}+\mathrm{C}$. farmeri and control. The viable population of $T$. parareesei, $T$. viride, $P$. variotii, $B$. thuringiensis and $C$. farmeri in different substrates was determined after 90, 180, 270, 360 and 450 days of inoculation following dilution plate technique to ascertain the best antagonist + substrate combination for highest shelf life of the formulation in storage at room temperature. On the basis of the highest recovery of the population of these antagonists ( $\mathrm{cfu} / \mathrm{g}$ ), the best substrate was selected for development of bioformulations consortia and further experimentations under field conditions.

2.6 Field evaluation of the substrate based bio-formulations against bacterial wilt of Naga chilli

The best three consortial bioformulations were applied in planta as combination of seed treatment, soil application at transplanting and spray at 30 days after transplanting to evaluate their efficacy to reduce wilt incidence vis a vis enhancement of crop yield. The consortial formulation of $T$. parareesei, T. viride and B. thuringiensis; T. parareesei, $T$. Viride, P. variotii, B. thuringiensis and C. farmeri was used for seed treatment, seedling treatment, soil application and their combinations. All together 6 (six) treatment combinations were compared (Table 3), arranged in RBD and each treatment was replicated four times.

\subsubsection{Seed treatment}

Naga chilli seeds were first surface sterilized with $1 \%$ sodium hypo chloride then rinsing them twice with sterile water and treated with each of the substrate based bioformulations @ $10 \mathrm{~g} / 100 \mathrm{~g}$ of seed along with a sticker/adhesive like rice glue for easy adherence. The coated seeds were then spread over a clean paper and dried overnight.

\subsubsection{Root treatment}

Substrate based bioformulations were mixed with clean water to form a fine slurry and the roots of the seedlings were dipped into the each slurry of each formulation for about 30 minutes. For 1000 seedlings $1 \mathrm{~kg}$ of bioformulations was required. The treated roots were dried for 1 hour under shade before transplanting.

\subsubsection{Soil treatment}

At the time of transplanting, $1 \mathrm{~kg}$ each of substrate based bioformulation was mixed with $10 \mathrm{~kg}$ of vermicompost and was applied to the soil near the root zone of plants @ $100 \mathrm{~g} /$ plant. Pot grown Naga chilli (var. Bor Bhoot) plants were inoculated with $R$. solanacearum $\left(10^{9} \mathrm{cfu} / \mathrm{ml}\right)$ by root inoculation technique (Winstead \& Kelman, 1952).

The control plants were treated with sterile distilled water before inoculation with the pathogen. Observations on percent wilting after 7days of inoculation were recorded and record of crop yield (kg) per plant harvested (pods plucked) 7 times at an interval of 10 days till crop maturity. 


\section{Results and Discussion}

\subsection{Isolation of pathogen and antagonists}

All the isolated microbial antagonists were identified on the basis of morphological, physiological and biochemical characteristics. The key identification characters and identified species on the behalf of these characteristics are as follows:

\subsubsection{Bacillus thuringiensis BTJ-S-1}

Gram-positive, spore-forming, rod-shaped bacteria, approx $1 \mathrm{x}$ $5 \mu \mathrm{m}$ in size with a diamond-shaped crystal; white to off-white colour colonies with smooth edges and slightly raised elevation (Fig. $1 \mathrm{G}$ ). The isolated bacterial strain showed mesophiles nature with temperature ranging from $30-45^{\circ} \mathrm{C}$, aerobic, chemoheterotrophs; found endospore and the parasporal bodies after staining with Coomassie Brilliant Blue R-250, hydrolysis of esculin and lecithin, utilization of sucrose, starch hydrolysis, gelatin hydrolysis and glucose and fructose fermentation test positive, production of indole and $\mathrm{H}_{2} \mathrm{~S}$ and fermentation of galactose and lactose negative (Hyakumachi et al., 2013)

\subsubsection{Trichoderma parareese $\mathrm{T}$ TPJ-S-1}

On PDA medium mycelium covers the plate within 3 days on incubation at $25 \pm 2^{\circ} \mathrm{C}$. Secondary hyphae formed a dense reticulum. After 6 days of incubation at $25^{\circ} \mathrm{C} \pm 2^{\circ} \mathrm{C}$ on PDA medium, at first colonies appear white, becoming light to dark green as conidia develop, production of conidia is abundant and variably superposed bright yellow-green to dark green pustules and give rise to a powdery to granular texture (Fig. 1 D). A bright yellow pigment diffuses into the PDA medium which is clearly visible in reverse side of the culture. Fungal conidia are ovoid to uniformly ellipsoidal, ellipsoidal to cylindrical at $37^{\circ} \mathrm{C}$ more variable, (3.3-6.2 X 2.5-3.5) $\mu \mathrm{m}$ in size, phialide lageni form or ampulli form, often with a cylindrical neck, usually with distinct widening at or above the middle (Fig. 1 A-C), length $4.5-11 \mu \mathrm{m}$, width at widest point 2.5-3.8 $\mu \mathrm{m}$, width at base 1.4-3.2 $\mu \mathrm{m}$ (Atanasova et al., 2010). The fungus are Mesophiles in nature $\left(25^{\circ} \mathrm{C}\right.$ to $\left.30^{\circ} \mathrm{C}\right)$ and typical aerobic.

\subsubsection{Citrobacter farmeri CTJ-S-1}

Gram negative, bacilli, $1.0 \times 2.0-6.0 \mu \mathrm{m}$, found singly or in pairs, frequently motile, peritrichous flagella, usually not encapsulated, nonspore forming, oxidase negative, utilization of acetic acid positive, Simmon's citrate negative, indole production positive, ornithine decarboxylase positive, malonate negative, $\mathrm{KCN}$ growth positive, sucrose positive, gelatinase positive, urease positive, fermentation of melibiose positive, utilization of Tween 80 and Tween 40 negative, utilization of Darabitol negative, utilization of sorbitol positive, methyl red positive, arginine dehydrolase positive, facultative anaerobes (Adams \& Boopathy, 2005).

\subsubsection{Trichoderma viride TVJ-S-1}

On PDA medium colonies are fast growing, conidiation are compact tufts like or more effuse, dark bluish-green (Fig. 1 F), typically uncoloured on reverse side, distinctly aromatic odour as of coconut. Conidiophores having a relatively loose arrangement with less branching, most often paired or single or three verticillate, often appeating flexous, Phialides arising singly or paired or 3-verticillate or narrowly logeniform, size (8-14 X 2.4-3.0) $\mu \mathrm{m}$. Conidal globose to ellipsoidal, often conspicuously warted, size (4.0-4.8 X 3.5-4.0) $\mu \mathrm{m}$, bluish to dark green in colour (Rifai, 1969). This is also a mesophilic $\left(25^{\circ} \mathrm{C}\right.$ to $\left.30^{\circ} \mathrm{C}\right)$ and typical aerobic fungi.

\subsubsection{Paecilomyces variotii Isolate-1}

Colonies of growing Paecilomyces variotii Isolate-1 rapidly growing on PDA medium and produced powdery to floccose, funiculose or tufted, yellow-brown or sand colored mycelium of the medium (fig 1.E). Conidiophores are verticillately arranged, branches with phialides up to $150 \mu \mathrm{m}$ in length, 3.5$6.5 \mu \mathrm{m}$ width. Phialides are cylindrical or ellipsoidal, tapering abruptly into a long, thin, cylindrical neck. Conidia of the fungi are subspherical, ellipsoidal to fusiform in shape and hyaline 35 x 2-4 $\mu \mathrm{m}$, arising in long, divergent chains. Black pigment visible in reverse side of the culture (Samson 1974).

\subsection{Molecular characterization of antagonists}

Identification of the antagonists by using ribosomal DNA based partial sequencing tool clearly validated that the five microbial strains are member of potential microbial antagonist's community based on their nucleotide homology and phylogenetic analysis. The 16S rRNA gene sequence of the tested bacterial antagonist BTJ-S-1 was identified as $B$. thuringiensis which showed $100 \%$ sequence identity with $16 \mathrm{~S}$ rRNA gene sequence of $B$. thuringiensis strains Et10/1 (Accession: KJ722441.1) and EAPL02 (Accession: JX500174.1). The other bacterial antagonist (CTJ-S-1) was diagnosed as C. farmeri where $100 \%$ sequence similarity was observed with $16 \mathrm{~S}$ rDNA gene sequence of $C$. farmeri, strain: GTC 01319 (Accession: AB741662.1). Submission of 18S rDNA partial sequence segment of the fungal antagonist (Isolate-1) into NCBI BLASTn indicated that the isolate is $P$. variotii which exhibited $99 \%$ sequence identity to $18 \mathrm{~S}$ ribosomal RNA gene sequence of $P$. variotii strain KUC5015 (Accession: GQ241284.1) and isolate SUMS0303 (Accession: FJ011547.1). The BLAST search of 28S rDNA gene fragment of two tested fungal antagonists TPJ-S- 1 and TVJ-S-1 in NCBI BLASTn indicated that the isolates are $T$. parareese $i$ and $T$. viride respectively. TPJ-S-1 isolate showed $100 \%$ sequence similarity with $T$. parareesei strain ATCC MYA-4777 (Accession: JN874490.1) whereas 99\% sequence identity was observed in tested fungal antagonist TVJ-S-1 with T. viride strain KSAP113 (Accession: GQ408917.1). 


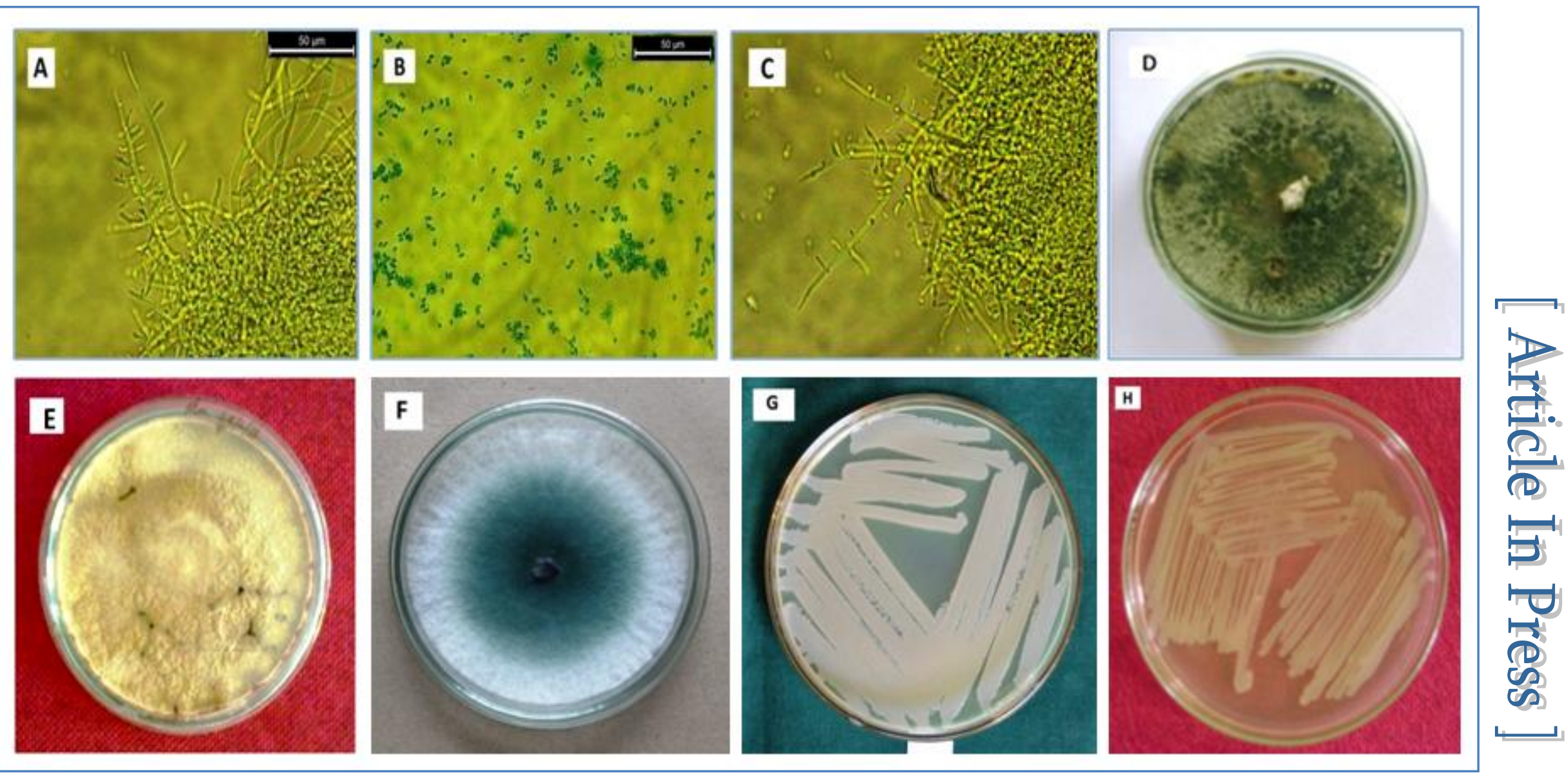

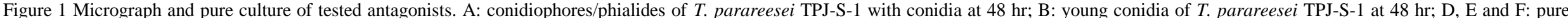

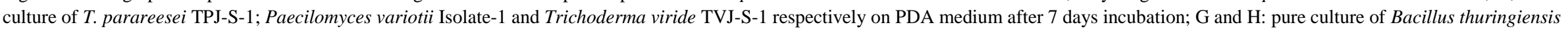
BTJ-S-1 and Citrobacter farmeri CTJ-S-1 respectively. 


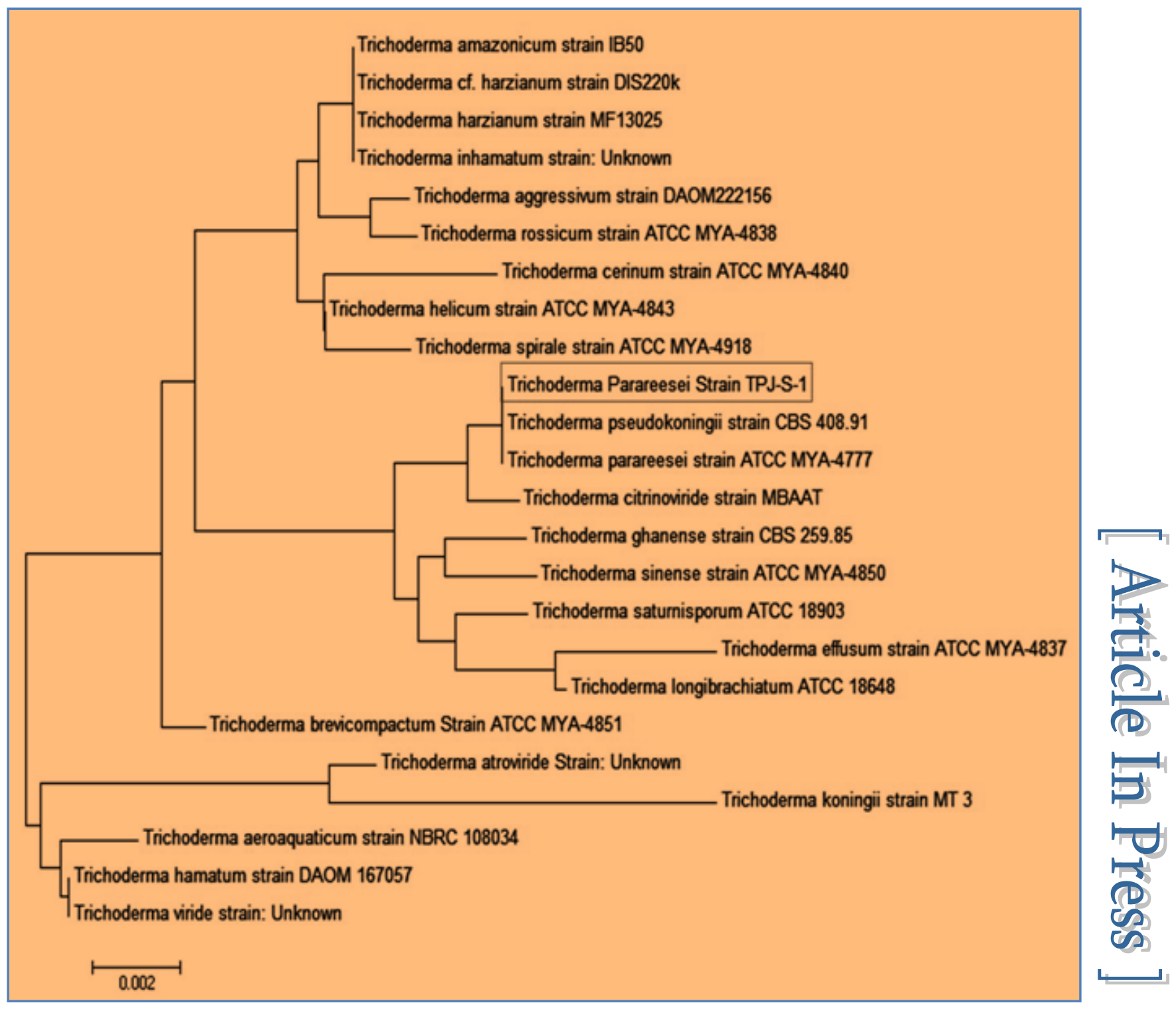

Figure 2 28S rDNA gene sequence based neighbor-joining phylogenetic tree illustrating genetic relationship of tested antagonist $T$. parareese $i$ TPJ-S-1 with few members of the genera Trichoderma.

3.3 Nucleotide sequences accession numbers

All the sequences have been deposited in GenBank database under accession no KF439054 (Bacillus thuringiensis BTJ-S1), KF439053 (Paecilomyces variotii Isolate-1), KF439052 (Trichoderma parareesei TPJ-S-1), KF439055 (Trichoderma viride TVJ-S-1), KF439051 (Citrobacter sp.).

3.4 Multiple sequence alignments and phylogenetic analysis

Phylogenetic analysis of $T$. parareesei TPJ-S-1 and $B$. thuringiensis BTJ-S-1 at nucleotide level showed close relationship of these bioagents to their close antagonistic relatives reported previously. This will help to understand the molecular basis of their antagonistic properties and to determine phylogenetic relationships with pathogenic species. $28 \mathrm{~S}$ rDNA gene fragment based multiple sequence alignments and phylogenetic analysis of $T$. parareesei TPJ-S-1 yielded higher resolution discrimination between other closely related Trichoderma species. Phylogenetic tree analysis showed 100\% identity of $T$. parareese TPJ-S-1(Accession: KF439052) with T. pseudokoningii CBS 408.91(Accession: AF400740.1) and T. parareesei strain ATCC MYA-4777 and distance relationship with previously reported successful antagonist species T. viride, T. koningii, T. harzianum etc (Fig. 2). The tested antagonist $T$. parareese $i$ TPJ-S-1 can be placed in same 
cluster with $T$. citrinoviride strain MBAAT (Accession: KF380830.1), T. ghanense strain CBS 259.85 (Accession: AF399234.1), T. sinense strain ATCC MYA-4850 (Accession: KC171318.1), T. saturnisporum ATCC 18903 (Accession: AF399246.1), T. effusum strain ATCC MYA-4837 (Accession: KC171306.1). Whereas in 16S rDNA based neighbour-joining phylogenetic tree analysis, B. thuringiensis BTJ-S-1 showed close relationship with $B$. thuringiensis strain Et10/1, B. cereus strain Bactisubtil and formed a cluster with $B$. muralis strain LMG 20238, $B$. simplex strain LMG 11160, $B$. psychrosaccharolyticus strain unknown, B. acidiceler CBD 119, B. isronensis strain B3W22, B. coahuilensis strain m4-4, B. mycoides strain unknown (Fig. 3).

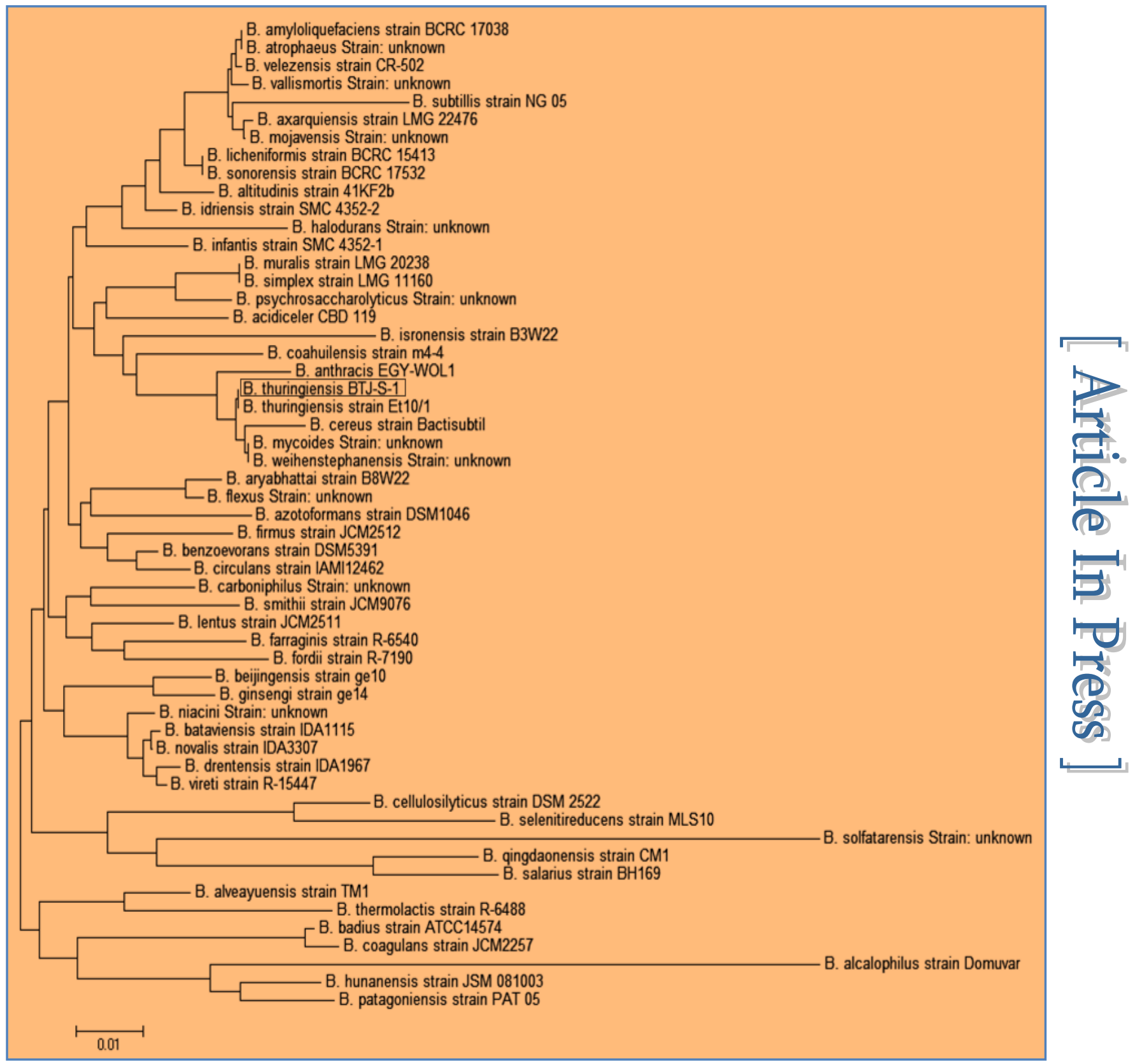

Figure 3 16S rDNA gene sequence based neighbour-joining phylogenetic tree illustrating genetic relationship of tested antagonist Bacillus thuringiensis BTJ-S-1 with few members of the genera Bacillus. 
3.5 Inhibitions of $R$. solanacearum by antagonists and their consortia in vitro

The data representing inhibitions by the five antagonists and their consortia against $R$. solanacearum in TTC media were recorded and are presented in Table 1 . The highest inhibition of $R$. solanacearum was recorded by consortia of $T$. parareesei $+T$. viride $+B$. thuringensis $(91.47 \%)$ which was followed by the consortia of $T$. parareese + T.viride $+P$. variotii $+B$. thuringensis $+C$. farmeri $(82.22 \%)$; and consortia of $T$. parareesei $+T$. viride $+P$. variotii $(79.24 \%)$. The inhibition zone produced by $C$. farmeri in all the treatment combination consortia was found to be less as compared to other antagonists. Based on the ability of the consortia to inhibit the growth of $R$. solanacearum in vitro, these four consortia were selected for further experimentations.

Table 1. Inhibition Zones produced by antagonists and their combinations against $R$. solanacearum dual cultured in TTC media.

\begin{tabular}{|c|c|c|}
\hline Treatments & $\begin{array}{l}\text { Inhibition Zone } \\
(\mathrm{mm})^{*}\end{array}$ & $\begin{array}{l}\text { Inhibition of } R \text {. } \\
\text { solanacearum }(\%)\end{array}$ \\
\hline$T$. parareese $i+R$. solanacearum & 27.33 & 30.36 \\
\hline T. viride $+R$. solanacearum & 41.50 & 46.11 \\
\hline$P$. variotii $+R$. solanacearum & 25.00 & 27.77 \\
\hline B. thuringensis $+R$. solanacearum & 22.33 & 24.81 \\
\hline C. farmeri $+R$. solanacearum & 17.66 & 19.62 \\
\hline T. parareesei $+T$. viride $+R$. Solanacearum & 64.00 & 71.11 \\
\hline T. parareesei $+P$. variotii $+R$. Solanacearum & 62.00 & 68.88 \\
\hline T. parareesei + B. thuringensis $+R$. Solanacearum & 47.34 & 52.60 \\
\hline T. parareesei $+C$. farmeri $+R$. Solanacearum & 56.83 & 63.14 \\
\hline$T$. viride $+P$. variotii $+R$. Solanacearum & 49.84 & 62.22 \\
\hline$T$. viride + B. thuringensis $+R$. Solanacearum & 50.83 & 56.47 \\
\hline T. viride + C. farmeri $+R$. Solanacearum & 48.00 & 53.33 \\
\hline$P$. variotii $+B$. thuringensis $+R$. solanacearum & 42.16 & 46.84 \\
\hline$P$. variotii $+C$. farmeri $+R$. solanacearum & 39.99 & 44.43 \\
\hline B. thuringensis $+C$. farmeri $+R$. Solanacearum & 31.99 & 35.54 \\
\hline$T$. parareesei $+T$. viride $+P$. variotii $+R$. Solanacearum & 71.32 & 79.24 \\
\hline T. parareesei $+T$. viride $+B$. thuringensis $+R$. Solanacearum & 82.33 & 91.47 \\
\hline$T$. parareese $+T$. viride $+C$. farmeri $+R$. solanacearum & 67.83 & 75.36 \\
\hline T. parareesei $+P$. variotii $+B$. thuringensis $+R$. solanacearum & 62.17 & 69.07 \\
\hline$T$. parareesei $+P$. variotii $+C$. farmeri $+R$. solanacearum & 67.16 & 74.62 \\
\hline T. parareesei + B. thuringensis $+C$. farmeri $+R$. solanacearum & 55.33 & 61.47 \\
\hline$T$. viride $+P$. variotii $+B$. thuringensis $+R$. solanacearum & 57.16 & 63.51 \\
\hline$T$. viride $+P$. variotii $+C$. farmeri $+R$. solanacearum & 56.49 & 62.76 \\
\hline T. viride $+B$. thuringensis $+C$. farmeri $+R$. solanacearum & 44.33 & 49.25 \\
\hline$P$. variotii $+B$. thuringensis $+C$. farmeri $+R$. solanacearum & 26.16 & 29.06 \\
\hline$T$. parareesei $+T$. viride $+P$. variotii $+B$. thuringensis $+R$. solanacearum & 52.56 & 58.50 \\
\hline$T$. parareesei $+T$. viride $+P$. variotii $+C$. farmeri $+R$. solanacearum & 67.98 & 75.53 \\
\hline T. parareesei $+P$. variotii + B. thuringensis $+C$. farmeri $+R$. solanacearum & 48.49 & 53.87 \\
\hline$T$. viride $+P$. variotii $+B$. thuringensis $+C$. farmeri $+R$. solanacearum & 48.32 & 53.68 \\
\hline$T$. parareesei $+T$. viride $+P$. variotii + B. thuringensis $+C$. farmeri $+R$. & 74.00 & 82.22 \\
\hline Control (R. solanacearum alone) & 0.00 & 0.00 \\
\hline $\begin{array}{l}\text { SEd }( \pm) \\
\operatorname{CD}(\mathbf{P}=0.05)\end{array}$ & & $\begin{array}{l}2.63 \\
5.24 \\
\end{array}$ \\
\hline
\end{tabular}


3.6 Mass multiplication of the antagonists on various substrates

The mean population $\left(64.55 \times 10^{7} \mathrm{cfu} / \mathrm{g}\right)$ of all the five antagonists in formulations of three substrates significantly increased up to 270 days of storage after which it showed declining trend (Table-2). The highest population of $T$. viride $\left(112.43 \times 10^{7} \mathrm{cfu} / \mathrm{g}\right)$ was recovered from vermicompost based formulation, which was followed by population of $T$. parareesei $\left(108.83 \times 10^{7} \mathrm{cfu} / \mathrm{g}\right)$ after 270 days of storage. Among different antagonists, the recovery of $T$. viride was significantly higher in all the three substrates evaluated, while the recovery of Citobacter farmeri was significantly lower after different days of storage, the lowest recovery being (1.50 X $10^{7} \mathrm{cfu} / \mathrm{g}$ ) after 450 days of storage. Similarly, amongst different days of storage, least mean population of all antagonists $\left(5.20 \times 10^{7} \mathrm{cfu} / \mathrm{g}\right)$ was recovered after 450 days of storage. On an average, vermicompost among the substrates appeared to be the best nutrient source to support the antagonists for maximum multiplication and subsequently better disease reduction. Earlier, Suslow \& Schroth (1982) reported that bacterial antagonists like $P$. fluorescens could survive 7 months to 1 year with a higher population level when it was incorporated into carrier materials viz., talc or peat along with CMC. The higher population of bacterial antagonists like B. thuringiensis and $C$. farmeri might be due to high nutrient content of vermicompost, which is a good source of humus, Vitamin-B, auxin and antibiotics. Moreover, it contains 2.5-3.5 per cent nitrogen, 1.5-2.0 per cent phosphorous and 2.0-3.5 per cent potassium (Kohli et al., 1988). Vermicompost causes a shift of $\mathrm{pH}$ towards neutral, a reduction in electrical conductivity, and as most of the antagonists which prefers neutral to alkaline $\mathrm{pH}$ tends to exhibit higher population shift in vermicompost (Alexander, 1997). CMC was used in the formulation as an adhesive, which might have also played a role of preservative for the long-term viability of the antagonist. Moreover, mannitol used as osmoticant, has the ability to protect the antagonist from desiccation and thereby increases their survival (Vidhyasekaran \& Muthamilan, 1995). The fungal antagonist $T$. viride, $T$. parareesei and $P$. variotti also higher population count when vermicompost was used as its substrate, where these might have congenially favored by nutrients for better sporulation and production of colony forming units. Other attributes of fungal antagonists like, production of enzymes like $\beta-1-3$ glucanase and chitinase might have higher in vermicompost and thus have helped the fungi during utilization of cellulose and chitin present in different substrates (Hadar et al., 1979). Trichoderma spp multiply faster at higher concentration of $\mathrm{CO}_{2}$, a condition favoured by different substrates. Similarly, their multiplication might also been favored by humic acid present in the substrates (Ushasree et al., 1989).

3.7 Efficacy of the substrate based formulations of antagonists and their consortia in reduction of bacterial wilt incidence of Naga chilli
The formulations of antagonist consortia which showed comparatively better in vitro inhibition of the wilt pathogen $R$. solanacearum viz., consortia of $T$. parareesei $+T$. viride $+B$. thuringiensis; $T$. parareesei + T.viride $+P$. variotii $+B$. thuringiensis $+C$. farmeri $;$. parareese $i+P$. variotii $+B$. thuringiensis and $T$. parareese $+T$. viride $+P$. variotii were further evaluated for their ability to suppress wilt disease in Naga chilli under field condition by seed, root and soil treatment/application methods. A mixture of $\mathrm{COC}(0.2 \%)$ and Streptocycline $(0.1 \%)$ was also applied similarly for comparison. The data representing disease suppression (\%) and yield ( $\mathrm{kg} / \mathrm{plant})$ are presented in Table 3 .

All the antagonist consortia as well as mixture of COC and Streptocycline were significantly effective in lowering the wilt incidence of Naga chilli (Table 3). However, a consortium of T. parareesei + T.viride $+P$. variotii + B. thuringiensis $+C$. farmeri was significantly most effective in reducing disease incidence. Data also depicted that the mixture of COC and Streptocycline was least effective in reducing disease incidence.

Better disease reduction in tomato caused by $R$. solanacearum was earlier recorded by using an antagonistic bacterium like $P$. fluorescens as seed and seedling inoculation, and the antagonistic ability and subsequent reduction of plant disease was attributed to its ability to produce siderophores (Aspiras \& Della, 1985), antibiotics and rapid colonization (Kloepper \& Schroth, 1981). Fungal antagonists like $T$. viride along with vermicompost as substrate, was reported to be highly effective in reduction of disease incidence in ginger (Bora et al., 2013). Vermicompost might have helped the fungal antagonists like $T$. viride, T. parareesei and $P$. variotti for better sporulation, production of colony forming units and subsequent higher reduction of wilt incidence in Naga chilli. Furthermore, Danielson \& Davey (1973) reported that Trichoderma spp multiply faster at higher concentration of $\mathrm{CO}_{2}$ and substrates like vermicompost containing high carbon. From above discussion, it is evident that substrate like vermicompost enhances the activity of antagonists, which complete with the soil borne plant pathogen for nutrient and space.

The addition of antagonists along with different substrates might have influenced of soil organic carbon. Earlier, Hoitink \& Fahy (1986) tried to establish positive correlation between $\mathrm{C}: \mathrm{N}$ ratio of residues of organic carbon and disease severity. Similarly, an increase in the available phosphorus content of soil has been reported to be effective in suppressing the disease incidence. The substrates particularly vermicompost increases available phosphorus content in the soil in contrast to the other treatment, which could provide maximum protection to the plants from the disease. The increased availability of phosphorus and potash in soil might have contributed towards the resistance of the plants to the diseases as have been recorded in many other pathogens (Sharif Hossain et al., 2003). 
Table 2 Population of Trichoderma parareesei, Trichoderma viride, Paecilomyces variotii, Bacillus thuringensis and Citrobacter farmeri assayed from substrate based bioformulations after different days of storage.

\begin{tabular}{|c|c|c|c|c|c|c|}
\hline \multirow[t]{2}{*}{ Treatments } & \multicolumn{6}{|c|}{ Population of antagonists (x $10^{7} \mathrm{cfu} / \mathrm{g}$ ) after different days of storage ${ }^{*}$} \\
\hline & 90 & 180 & 270 & 360 & 450 & Mean \\
\hline Vermicompost $(\mathrm{VC})+T$. parareesei & $62.83(1.80)$ & $91.17(1.96)$ & $108.83(2.04)$ & $71.50(1.85)$ & $7.50(0.87)$ & $68.37(1.83)$ \\
\hline Talc powder $(\mathrm{TC})+T$. parareesei & $44.55(1.65)$ & $67.50(1.81)$ & $79.66(1.66)$ & $75.27(1.87)$ & $22.15(1.33)$ & $57.83(1.76)$ \\
\hline Mustard oil cake $(\mathrm{MOC})+T$. parareese $i$ & $40.50(1.61)$ & $48.50(1.68)$ & $59.33(1.77)$ & $65.33(1.81)$ & $58.00(1.76)$ & $54.33(1.73)$ \\
\hline $\mathrm{VC}+T$. viride & $64.33(1.80)$ & $90.50(1.96)$ & $112.43(2.05)$ & $86.10(1.93)$ & $16.48(1.21)$ & $73.97(1.87)$ \\
\hline $\mathrm{TC}+T$. viride & $43.50(1.64)$ & $59.50(1.77)$ & $71.17(1.85)$ & $39.06(1.59)$ & $14.50(0.87)$ & $45.55(1.65)$ \\
\hline $\mathrm{MOC}+T$. viride & $27.33(1.44)$ & $43.00(1.63)$ & $61.66(1.79)$ & $36.50(1.56)$ & $24.33(1.39)$ & $38.56(1.59)$ \\
\hline $\mathrm{VC}+P$. variotii & $34.50(1.54)$ & $60.00(1.77)$ & $72.88(1.86)$ & $57.87(1.76)$ & $7.45(0.87)$ & $46.54(1.66)$ \\
\hline $\mathrm{TC}+P$. variotii & $25.99(1.41)$ & $49.50(1.69)$ & $51.50(1.71)$ & $33.10(1.52)$ & $1.50(0.17)$ & $32.32(1.51)$ \\
\hline $\mathrm{MOC}+P$. variotii. & $15.66(1.19)$ & $45.66(1.66)$ & $47.33(1.67)$ & $20.66(1.31)$ & $0.83(0.08)$ & $26.03(1.41)$ \\
\hline $\mathrm{VC}+B$. thuringensis & $16.50(1.22)$ & $26.50(1.42)$ & $27.89(1.44)$ & $22.17(1.35)$ & $5.30(0.72)$ & $19.67(1.29)$ \\
\hline $\mathrm{TC}+B$. thuringensis & $11.27(1.05)$ & $22.40(1.35)$ & $38.17(1.58)$ & $25.50(1.40)$ & $11.50(1.06)$ & $21.77(1.34)$ \\
\hline $\mathrm{MOC}+B$. thuringensis & $13.50(1.13)$ & $21.66(1.33)$ & $32.33(1.51)$ & $18.33(1.26)$ & $6.00(0.78)$ & $18.36(1.26)$ \\
\hline $\mathrm{VC}+C$. farmeri & $21.27(1.33)$ & $52.40(1.72)$ & $48.17(1.68)$ & $35.50(1.55)$ & $1.55(0.19)$ & $31.78(1.50)$ \\
\hline $\mathrm{TC}+C \cdot$ farmeri & $15.50(1.19)$ & $16.50(1.22)$ & $34.80(1.54)$ & $9.30(0.96)$ & $1.50(0.17)$ & $15.52(1.19)$ \\
\hline \multirow[t]{2}{*}{ MOC + C. farmeri } & $12.66(1.10)$ & $15.33(1.18)$ & $31.00(1.49)$ & $5.50(0.74)$ & $1.50(0.18)$ & $13.20(1.12)$ \\
\hline & $29.99(1.48)$ & 45.57 (1.66) & $58.48(1.77)$ & $40.11(1.60)$ & $12.01(1.08)$ & \\
\hline
\end{tabular}

S.Ed. $\pm=$ For treatment $=0.022$, for days $=0.016$, for treatment $\mathrm{x}$ days $=0.042 ; \mathrm{CD}(\mathrm{P}=0.05)=$ For treatment $=0.044$, for days $=0.032$, for treatment $\mathrm{x}$ days $=0.084$; *Figures in the parentheses are logarithm-transformed values.

Table 3 Efficacy of substrate based bioformulations of antagonists and their consortia on reduction of bacterial wilt incidence and yield of Naga chilli.

\begin{tabular}{|c|c|c|c|}
\hline Treatment & Disease incidence $(\%)^{*}$ & Disease reduction $(\%)$ & Yield (qt/ha) \\
\hline Consortia of T. parareesei, $T$. viride, and P. variotii & $63.20(53.72)$ & 26.16 & 30.80 \\
\hline Consortia of T. parareesei, T. viride and B. thuringiensis & $49.6(45.10)$ & 42.05 & 58.80 \\
\hline Consortia of T. parareesei, $P$. variotii and B. thuringiensis & $31.8(34.36)$ & 62.85 & 74.20 \\
\hline $\begin{array}{l}\text { Consortia of } T . \text { parareesei, } T . \text { viride, } P . \quad \text { variotii, } B . \\
\text { thuringiensis and } C \text {. farmeri }\end{array}$ & $13.8(19.20)$ & 83.87 & 96.80 \\
\hline COC + Streptocycline & $57.60(50.96)$ & 21.02 & 17.06 \\
\hline Control & $85.60(68.81)$ & & 3.70 \\
\hline $\begin{array}{l}\text { S.ed }( \pm) \\
\text { CD }(P=0.05)\end{array}$ & $\begin{array}{c}6.82 \\
11.68 \\
\end{array}$ & & $\begin{array}{l}3.65 \\
6.24 \\
\end{array}$ \\
\hline
\end{tabular}

*Figures in the parentheses are angular transformed values.

3.8 Efficacy of the substrate based formulations of antagonists and their consortia on yield enhancement of Naga chilli (t/ha)

The yield of the Naga chilli significantly increased when plants were treated with $T$. parareesei, T.viride, P. variotii, $B$. thuringiensis and $C$. farmeri based consortia bioformulation, following different methods (Table 3 ).

Successful biological control agents T. viride and T. parareesei have the ability to compete with other members of the soil microflora and also to produce antibiotics or induce a response in the host that favors the growth of the plant beneficial microbes while inhibiting the growth of the pathogen like $R$. solanacearum. Simultaneous application of two or more compatible antagonists led to their higher population densities in the rhizosphere and the density dependent mechanism might have prevailed by rapid rhizosphere colonization, and thereby led to rhizosphere niche exclusion in terms of space and nutrients for the pathogen and ultimately reduction of wilt incidence and corresponding enhancement of crop yields. Such mechanisms have been demonstrated by Bull (1987), and explained that the wheat take-all disease control and enhancement of crop yield by biological means was directly related to the rapid root colonization by antagonist like $P$. fluorescens. Moreover, the efficiency of biocontrol agents with organic substrates is depended on method of introduction, rate 
of inoculum density of the bioagents applied against the pathogens (Papavizas, 1985). Parakhia \& Vaishnav (1986) observed that seed treatment with wheat husk-bran culture of $T$. harzianum followed by soil drenching could successfully control $R$. bataticola infection in chick pea and increase crop yield. Similarly, Vidya (1995) used combination of talc-based formulation of $T$. harzianum + vermiculite-wheat bran formulation for soil application and effectively managed $M$. phaseolina root rot disease of mung bean resulting higher crop yield. Biological control of plant diseases by using plant associated microorganisms is an eco friendly approach (Bargabus et al., 2003; Tjamos et al., 2005). Mandal et al. (2013) reported that Gram-negative genera Citrobacter and Enterobacter belonging to the family Enterobacteriaceae could produce multiple antimicrobial lipopeptides like fengycin analogues and isomer of iturins, fengycins, kurstakins surfactins etc active against $P$. aeruginosa, Micrococcus luteus and Staphylococcus aureus. Several antagonistic bacterial species from the family Enterobacteriaceae have been reported to suppress root pathogens of various plants. For example root associated bacteria Citrobacter freundii and Enterobacter cloacae have been found to reduce root associated diseases in lemon plants (Lima et al., 1994; Araújo et al., 2001). Xue et al. (2009) reported that, Enterobacter sp. (family Enterobacteriaceae) could show good bio control potential against bacterial wilt pathogen $R$. solanacearum with a control efficacy up to $65 \%$ under field condition. They also mentioned that this antagonist bacteria possessed plant growth promoting properties and could enhance plant biomass by $23.0 \%$.

The naturally abundant Gram-positive bacteria species of the genus Bacillus are known to produce large number of antimicrobial lipopeptides (Nybroe \& Sørensen, 2004; Ongena \& Jacques, 2008). The cyclic lipopeptide biosurfactants like iturin, mycosubtilin, surfactin and kurstakin produced by species of Bacillus have strong antimicrobial activity (Rodrigues et al., 2006; Raaijmakers et al., 2010). The wellknown bio-insecticide B. thuringiensis (Roh et al., 2007) recently, attracted considerable attention as a potential biological control agent for the suppression of plant diseases. This species can be characterized by the production of crystal proteins (d-endotoxins) with a specific activity against insect pests, nematodes, mites and protozoa (Beegle \& Yamamoto 1992; Feitelson et al., 1992). Besides this, they also produces a number of extracellular compounds including phospholipases, chitinases, proteases (Lovgren et al., 1990), $\beta$ exotoxins, and antibiotic compounds with antifungal activity (Stabb et al., 1994). Most recently Hyakumachi et al. (2013) reported that, root treatment of tomato plants with $B$. thuringiensis culture could considerably reduce the bacterial wilt (c.o. Ralstonia solanacearum) of tomato to less than one third of the control. They attributed this phenomenon to systemic activation of plant defence system and expression of defence-related genes such as PR-1, acidic chitinase, and $\beta-1,3$ glucanase in stem and leaf tissues. Similar report also made by Takahashi et al. (2014) where they mentioned that SA-dependent signalling pathway and suppression of JA-dependent signalling pathway seem to play key roles in inducing resistance in tomato plants against $R$. Solanacearum.

\section{References}

Adams L, Boopathy R (2005) Isolation and characterization of enteric bacteria from the hindgut of Formosan termite. Bioresource Technology 96:1592-1598.

Alexander M (1997) Introduction to soil Microbiology. John Wiley and Sons, New York, Pp. 212.

Anuratha CS, Gnanamanickam SS (1990) Biological control of bacterial wilt caused by Pseudomonas solanacearum in India with antagonistic bacteria. Plant and Soil 124: 109-116.

Araújo WL, Maccheroni W Jr, Aguilar-Vildoso CI, Barroso PA, Saridakis HO, Azevedo JL (2001) Variability and interactions between endophytic bacteria and fungi isolated from leaf tissues of citrus rootstocks. Canadian Journal of Microbiology 47:229-236.

Askary H, Benhamou N, Brodeur J (1997) Ultrastructural and cytochemical investigations of the antagonistic effect of Verticillium lecanii on cucumber powdery mildew. Phytopathology, 87: 359-368.

Aspiras RB, Dela CAR (1985) Potential biological control of bacterial wilt in tomato and potato with Bacillus polymyxa $\mathrm{Fu}$ 6 and Pseudomonas fluorescens. In: Persely GD ( Ed) Bacterial Wilt Disease in Asia and the South Pacific, ACIAR Proceedings, No. 13, Pp. 89-92.

Atanasova L, Jaklitsch WM, Komoń-Zelazowska M, Kubicek CP, Druzhinina IS (2010) Clonal species Trichoderma parareesei sp. nov. likely resembles the ancestor of the cellulase producer Hypocrea jecorina/T. reesei. Applied and Environmental Microbiology.76: 7259-7267.

Bargabus RL, Zidack NK, Sherwood JE, Jacobsen BJ (2003) Oxidative burst elicited by Bacillus mycoides isolate Bac $\mathrm{J}$, a biological control agent, occurs independently of hypersensitive cell death in sugar beet. Molecular Plant Microbe Interactions 16: 1145-1153.

Beegle CC, Yamamoto T (1992) Invitation paper (C.P. Alexander Fund): History of Bacillus thuringiensis berliner research and development. The Canadian Entomologist 124: 587-616.

Bora LC (2011) Use of Pseudomonas fluorescens as a biopesticide for management of bacterial wilt disease caused by Ralstonia solanacearum. Tropical Agriculture 88: 97.

Bora LC, Deuri D, Kataky L (2013) RAPD analysis of ginger germplasms of North East India and assessment of their resistance against bacterial wilt disease caused by Ralstonia solanacearum. World Biodiversity Congress, Global Scientific 
Research Foundation, Chiang Mai \& Rajabhat University, Chiang Mai, Thailand.

Bosland PW, Baral JB (2007) 'Bhut Jolokia'-the world's hottest known chilli pepper is a putative naturally occurring interspecific hybrid. HortScience 42: 222-224.

Bull CT (1987) Wheat root colonization by disease suppressive bacteria and the effect of population size on severity of take-all caused by Gaeumannomyces graminis var. tritici M.S. Fleming West State Univ. Pullman. pp. 75-81.

Burr TJ, Schroth MN, Suslow T (1978) Increased potato yields by treatment of potato seedpieces with specific strains of Pseudomonas fluorescens and P. putida. Phytopathology 68: 1377-1388.

Chet I (1987) Trichoderma - application, mode of action, and potential as a biocontrol agent of soilborne plant pathogenic fungi. In: Chet I (Ed.), Innovative Approaches to Plant Disease Control, John Wiley \& Sons, New York pp. 137-160.

Danielson, RM, Davey CB (1973) Non-nutritional factors affecting the growth of Trichoderma in culture. Soil Biology and Biochemistry 5:495-504.

Elad Y, Chet I, Henis Y (1981) A selective medium for improving quantitative isolation of Trichoderma spp. from soil. Phytoparasitica 9:59-67.

Feitelson JS, Payne J, Kim L (1992) Bacillus thuringiensis: insects and beyond. Nature biotechnology 10: 271-275.

Hadar Y, Chet I, Henis Y (1979) Biological control of Rhizoctonia solani damping-off with wheat bran culture of Trichoderma harzianum. Phytopathology 69: 64-66.

Hermosa MR, Grondona I, Iturriaga EA, Diaz-Minguez JM, Castro C, Monte E, Garcia Acha I (2000) Molecular Characterization and Identification of Biocontrol Isolates of Trichoderma spp. Applied and Environmental Microbiology 66: $1890-1898$.

Hoitink HAJ, Fahy PC (1986) Basis for the control of soil borne plant pathogens with compost. Annual Review of Phytopathology 24: 93-144.

Hyakumachi M, Nishimura M, Arakawa T, Asano S, Yoshida S, Tsushima S, Takahashi H (2013 Bacillus thuringiensis Suppresses Bacterial wilt Disease Caused by Ralstonia solanacearum with Systemic Induction of Defense-Related Gene Expression in Tomato. Microbes and Environments 28: $128-134$.

James D, Girija D, Mathew SK, Nazeem PA, Babu TD, Varma AS (2003) Detection of Ralstonia solanacearum race 3 causing bacterial wilt of Solanaceous vegetables in kerala, using
Random Amplified Polymorphic DNA (RAPD) analysis. Journal of Tropical Agriculture 41: 33-37.

Kelman A (1954) The relationship of pathogeniciity in Pseudomonas solanacearum to colony appearance on a tetrazolium medium. Phytopathology 44: 693-695.

Kershaw MJ, Moorhouse ER, Bateman R, Reynolds SE, Charnley AK (1999) The Role of destruxinsin the pathogenicity of Metarhizium anisopliae for three species of insect. Journal of Invertebrate Pathology 74: 213-223.

King EO, Ward MK, Raney DE (1954) Two simple media for the demonstration of pyocyanin and fluorescin. The Journal of Laboratory and Clinical Medicine 44: 301-307.

Kloepper JW, Schroth MN (1981) Relationship of in vitro antibiosis of plant growth promoting rhizobacteria to plant growth and the displacement of root microflora. Phytopathology 71: 1020-1024.

Kohli RR, Srivastava AK, Shivankar VJ (1988) Organic culture in citrus cultivation. Indian Horticulture 43: 12-14.

Lima G, Ippolito A, Nigro F, Salerno M (1994) Attempts in the biological control of citrus mal secco (Phoma tracheiphila) using endophytic bacteria. Dif Piante 17:43-49.

Lövgren A, Zang MY, Engstöm A, Dalhammar G, Landen R (1990) Molecular characterization of immune inhibitor A, a secreted virulence protease from Bacillus thuringiensis. Moleculer Microbiology 4: 2137-2146.

Mandal SM, Sharma S, Pinnaka, Pinnaka AK, Kumari A, Korpole S (2013) Isolation and characterization of diverse antimicrobial lipopeptides produced by Citrobacter and Enterobacter. BMC Microbiology 13:152.

Manoranjitham SK, Prakasam V, Rajappan K, Amutha G (2000) Control of chilli damping-off using bioagents. Journal of Mycology and Plant Pathology 30: 225-228.

Nybroe O, Sorensen J (2004) Production of cyclic lipopeptides by fluorescent pseudomonads. In Ramos JL (Ed) Pseudomonas, Biosynthesis of Macromolecules and Molecular Metabolism. Kluwer Academic/ Plenum Publishers, New York: Pp 147-172.

Ongena M, Jacques P (2008) Bacillus lipopeptides versatile weapons for plant disease biocontrol. Trends in Microbiology 16:115-125.

Papavizas GC (1985) Trichoderma and Gliocladium : Biology, ecology and potential for biocontrol. Annual Review of Phytopathology 23: 23-54.

Parakhia AM, Vaishnav MU (1986) Biocontrol of Rhizoctonia bataticola. Indian Phytopathology 39: 439. 
Qing-Yun Xue, Yu Chen, Shi-Mo Li, Li-Feng Chen, GuoChun Ding, Da-Wei Guo, Jian-Hua Guo (2009) Evaluation of the strains of Acinetobacter and Enterobacter as potential biocontrol agents against Ralstonia wilt of tomato. Biological Control 48 252-258.

Raaijmakers JM, De Bruijn I, Nybroe O, Ongena M (2010) Natural functions of lipopeptides from Bacillus and Pseudomonas: more than surfactants and antibiotics. FEMS Microbiology Reviews 34:1037-1062.

Rifai MA (1969) A revision of the genus Trichoderma. Mycological Papers 116: 1-56.

Rodrigues L, Banat IM, Teixeira J, Oliveira R (2006) Biosurfactants potential applications in medicine. Journal of Antimicrobial Chemotherapy 57:609-618.

Roh JY, Choi J, Li MS, Jin BR, Je YH (2007) Bacillus thuringiensis as a specific, safe, and effective tool for insert pest control. Journal of Microbiology and Biotechnology 17: 547-559.

Samson RA (1974) Paecilomyces and some allied Hyphomycetes. Studies in Mycology 6: 1-119.

Samuels GJ, Ismaiel A (2009) Trichoderma evansii and $T$. lieckfeldtiae: two new T. hamatum like species. Mycologia 101: $142-156$

Sharif Hossain ABM, Hakim MA, Onguso JM (2003) Effect of manure and fertilizers on the growth and yield of potato. Pakistan Journal of Biological Sciences 6: 1243-246.

Stabb EV, Jacobson LM, Handelsman J (1994) Zwittermycin A-producing strains of Bacillus cereus from diverse soils. Applied and Environmental Microbiology 60: 4404-4412.

Suslow TV, Schroth MN (1982) Rhizobacteria of sugarbeets: effects of seed application and root colonization on yield. Phytopathology 72: 199-206.

Tajima F, Nei M (1984) Estimation of evolutionary distance between nucleotide sequences. Molecular Biology and Evolution 1: 269-85.

Takahashi H, Nakaho K, Ishihara T, Ando S, Wada T, Kanayama Y, Asano S, Yoshida S, Tsushima S, Mitsuro Hyakumachi (2014) Transcriptional profile of tomato roots exhibiting Bacillus thuringiensis induced resistance to Ralstonia solanacearum. Plant Cell Reports 33: 99-110.
Tamura K, Peterson D, Peterson N, Stecher G, Nei M, Kumar S (2011) MEGA 5: molecular evolutionary genetics analysis using maximum likelihood, evolutionary distance, and maximum parsimony methods. Molecular Biology and Evolution 28: 2731-2739.

Tjamos, SE, Flemetakis, E, Paplomatas, EJ, Katinakis, P (2005) Induction of resistance to Verticillium dahliae in Arabidopsis thaliana by the biocontrol agent K-165 and pathogenesis-related proteins gene expression. Molecular Plant Microbe Interactions 18: 555-561.

Ushasree, NN, Chandrasekaran, S, Govindasamy, R (1989) Humic acid and its influence on crop plants. In: National Seminar on Humic Acid in Agriculture. Annamalai University, Tamil Nadu (Abstr.), Pp. 63.

Vidhyasekaran, P, Muthamilan, M (1995) Development of formulations of Pseudomonas fluorescence for control of chickpea wilt. Plant Disease 79: 782-786.

Vidya, R (1995) Studies on biological control of mung bean root rot [Macrophomina phaseolina (Tassi)] Goid by Trichoderma viride Pers. M.Sc. Thesis submitted to Tamil Nadu Agriculture University, Coimbatore, India.

Vilgalys R, Hester M (1990). Rapid genetic identification and mapping of enzymatically amplified ribosomal DNA from several Cryptococcus species. Journal of Bacteriology $172: 4238-4246$.

Waksman SA (1922) A method of counting the number of fungi in the soil. Journal of Bacteriology 7: 339-341.

Wang C, Ramette A, Punjasamarnwong P, Zala M, Natsch A, Moenne-Loccoz Y, Defago G (2001) Cosmopolitan distribution of phlD-containing dicotyledonous cropassociated Biocontrol pseudomonads of worldwide origin. FEMS Microbiology Ecology 37: 105-116.

Weller DM, Cook RJ (1983) Suppression of take-all of wheat by seed treatments with fluorescent pseudomonads. Phytopathology 73: 463-469.

Winstead NN, Kelman A (1952) Inoculation techniques for evaluating resistance to Pseudomonas solanacearum. Phytopathology 42:628-634.

Xiaoke X, Xueting M, Miranda MH, Airong W, Shunxing G (2013) Genetic Diversity and Evolution of Chinese Traditional Medicinal Fungus Polyporus umbellatus (Polyporales, Basidiomycota). PLoS ONE 8: e58807. 